\title{
The experience of spirituality among institutionalized elderly people
}

\section{Abstract}

Objective: To identify the meanings attributed to the experience of spirituality when faced with life situations among elderly persons living in a long-term care facility. Method: A qualitative, exploratory and descriptive survey was carried out, based on interviews with eight elderly people living in a long-term care facility for the elderly in the state of Rio Grande do Sul, Brazil. Results: The content that emerged from the interviews underwent qualitative analysis for the extraction of units of significance and the elaboration of two thematic categories: Spirituality/religiosity as a direction of life and spirituality/religiosity as a meaning for life and a source of renewal, fulfilment and happiness. Conclusion: When describing the experience of spirituality as an important strategy for finding meaning in life, the elderly persons in this study revealed it to be a psychic and emotional support for coping with existential challenges. This knowledge allows professionals working in these institutions to invest in practices that incorporate spirituality as an element of the comprehensive care of the elderly.

\footnotetext{
Universidade de Passo Fundo, Faculdade de Educação Física e Fisioterapia, Programa de Pós-graduação em Envelhecimento Humano. Passo Fundo, Rio Grande do Sul, Brasil.

2 Universidade de Passo Fundo, Instituto de Ciências Biológicas, Faculdade de Enfermagem. Passo Fundo, Rio Grande do Sul, Brasil.
}

\section{Helenice de Moura Scortegagna \\ Nadir Antonio Pichler' \\ Lúcia Fernanda Fáccio²}

Keywords: Aging. Homes for the Aged. Spirituality. Religion and Science. 


\section{INTRODUCTION}

According to the Demographic Census of 2015 elderly persons in Brazil represent about $14.3 \%$ of the population ${ }^{1}$. Furthermore, according to data from the Institute of Applied Economic Research, 83,870 elderly people currently live in more than 3,500 long-term care facilities (LTCF) in the country. The option to seek an LTCF as a care option can mean protection and safety for the elderly ${ }^{2}$.

The contemporary reality of the demographic and epidemiological transformation of the Brazilian population, coupled with a marked transformation of family arrangements, has been reflected in the growing demand for such facilities as a form of social care.

This situation has created many challenges for health professionals, researchers, LTCF administrators, and the state itself, such as the fight against diseases and the provision of suitable environments for the carrying out of comprehensive, multidimensional care of the elderly, which should include reference to spirituality ${ }^{3}$. In this context, another challenge faced by LTCF professionals and managers is the provision of qualified care that respects the individuality and heterogeneity of each elderly person, considering the different postures of the elderly towards life ${ }^{4}$.

An LTCF, based on the National Policy for the Health of the Elderly Person regarding multidimensional care, should include not only physical, psychic, social and environmental factors, but also spiritual aspects, as a fundamental necessity for this stage of life 5 .

Spirituality, relating to questions of life and health, dates back to 2000-1800 BC, and remained an important part of caregiving until the middle of the fourteenth century, when Galileo brought about a separation of philosophy, science and religion. Since the end of the twentieth century, there has been a resumption of the approximation of these elements through the publications of epidemiological studies that have demonstrated the relationship between spirituality/religiosity and the health of patients ${ }^{6}$. Corroborating these results, studies on the topic of spirituality have found favorable outcomes for the improvement of the health and well-being of those who experience this phenomenon ${ }^{7,8}$.

Faced with this evidence, many studies have sought to address the issue of spirituality, based on the understanding that it has a beneficial influence in coping with diseases and adverse situations, having a protective effect against their negative impact on daily life ${ }^{9,10}$. Thauvoye et al. ${ }^{11}$, however, stated that some research on religion and spirituality is inspired by religious traditions and lifestyles, using a unilateral religious focus for the elaboration of instruments incorporated in a specific religious context, usually the Judeo-Christian tradition. The same authors also argue that it is necessary to gauge the three dimensions of spirituality: connectivity with the transcendent, with others and with nature.

Spirituality, although of a complex nature, has shown a positive association with well-being, constituting an important predictor of late life functioning, in relation to the care of the elderly. However, it is important to understand how each spiritual path is related to well-being, considering the individual preferences for one or more types of spiritual connection ${ }^{11}$.

As a concept, while spirituality differs from religiosity, both are based on the presence of something transcendent, experienced in the everyday as a capacity to transform life. Religion or religiosity comes from the Latin religio and the means to reconnect man with the supernatural, as a guarantee of salvation, based on a set of techniques, creeds, dogmas and rites instituted by institutions that profess such religions, such as Judaism, Christianity, Islam. Spirituality, meanwhile, has a more encompassing existential meaning. It deals with meaning, care, freedom, friendship, fraternity, hospitality, communion, quality of life and happiness. Its scope extends "beyond the biological dimension and logic dictated by time, the absolute carnality of the body and the preoccupation with unlimited material production"'"12. Furthermore, "spirituality refers to a universal question related to the meaning and purpose of life" $"$.

According to Pessini ${ }^{14}$, in the new millennium, universities and science have been surprised by the "rebirth of religion", that is, the emergence "of 
religions in all spheres of human life". In view of this, spirituality and/or religiosity are often employed by the elderly as a form of shelter during exposure to stressful situations, such as family problems, illness, their awareness of existential finitude and the process of institutionalization, which often occurs against their will ${ }^{15}$.

The present study contributes to the discussion of how spirituality/religiosity, as an intrinsic characteristic of being, can be seen as a mediator for institutionalized elderly persons when facing existential challenges, sufferings, anguish and as a support through faith. It can also be seen as a support for professionals when incorporating spirituality as an element in the integral care of the elderly.

Drawing on the understanding of Born ${ }^{16}$ that human beings have two significant dimensions in life - spiritual and material - and that, over time, the former grows in importance, and that caregivers of the elderly need to address the spiritual experience and not merely restrict their attention to physical aspects, the purpose of the present study was to identify the meanings attributed to the experience of spirituality when faced with the situations of life of elderly people living in a long-term care facility.

\section{METHOD}

An exploratory and descriptive study was performed as a subproject of the Scenarios of long-term care: Evaluation, intervention and educational possibilities in gerontological care integrated project.

The study was carried out in a private institution, located in a rural municipal region in the state of Rio Grande do Sul, Brazil, with a maximum capacity for 30 elderly people. The choice was intentional and based on the fact that the center offered spiritual care to the elderly.

Eight (26.6\%) elderly residents participated in this study after signing a Free and Informed Consent Term. The selection of the participants met the inclusion criteria: age 60 or older, residing in the LTCF, being male or female, voluntarily participating and having sufficient cognitive understanding to answer the questions. Elderly persons with a diagnosis of dementia and those with cognitive impairment, classified as grade III for dependence, were excluded ${ }^{17}$.

In order to collect data, the participants were approached inside the facility and chose a location where they would respond to the interview on an individual basis. This took place in April 2016, at a date and time arranged with the LTCF manager, respecting the programmed activities of the institution. A semi-structured questionnaire was used, with questions about the spirituality/ religiosity of the elderly; the importance attributed to the same in coping with and understanding the difficulties of life, and the frequency of its practice. The material that was obtained from the interviews underwent thematic content analysis, in accordance with Bardin ${ }^{18}$, which took the form of pre-analysis, investigation and interpretation of the material, allowing the extraction of units of significance and the elaboration of thematic categories through established semantic criteria based on the objective of the study.

In order to preserve the anonymity of the interviewees, in accordance with the ethical principles established by Resolution $N^{\circ} 466 / 12$ of the National Health Council, their names were substituted with the names of flowers. The study was approved by the Ethics Research Committee of the Universidade de Passo Fundo (approval no. 393/2011).

\section{RESULTS AND DISCUSSION}

The LTCF is home to more women than men, which reflected the profile of those selected for the study in terms of gender, as of the eight elderly participants, seven were female and one was male. The ages ranged from 61 to 88 years, with the mean age being 75 years. The female prevalence in this study agrees with studies performed with this population and reflects the feminization of old age $^{19}$. All the interviewees said they were religious and actively experienced their spirituality/religiosity.

From the investigation of the material it was possible to construct the following categories: Spirituality/religiosity as a direction and encouragement for 
life; spirituality/religiosity as a meaning for life and a source of renewal, fulfillment and happiness.

It is worth noting that the findings identified a relationship between spirituality and religiosity in the discourse of the elderly. This, according to Vitorino and Vianna, ${ }^{15}$ is not exclusive to the elderly, but a mixture of concepts that permeates much of society.

\section{Spirituality/religiosity as a direction}

and encouragement for life

From the expressions of the elderly about spirituality and its importance for their direction of life, this concept can be seen as a substantial support for the good quality of life of these elders, according to the dictates of their conscience. When questioned about the importance of spirituality, the elderly referred to it as a tool to avoid deviating from the right path and remaining firm in what they have learnt, as can be seen below:

“To avoid going down the wrong path [...] stealing, prostitution and so on. Dishonesty. When this new generation was born responsibility was taking a holiday. They lost their balance. The parents aren't to blame, they were born this way" (Rose).

"People need to know what they're doing" (Lily).

"I like my children, they don't smoke, they don't drink, they do the right thing" (Bromeliad).

"It's important to hold the word of God in our hearts and not sin against the Lord" (Narcissus).

In this sense, Gutz and Camargo ${ }^{13}$ identified that the social representation of spirituality for the elderly is anchored in divine protection in the face of everyday situations; in the transcendence of worldly existence; in the quality of thought, considering the importance of honesty in interpersonal living and human responsibility in the choices and possible consequences of life.

The experience of practicing religion in the family emerged in the discourse, revealing the importance of tradition, taught by their parents while still in infancy, as a factor of the significant presence of religiosity, even in the advanced phases of life, illustrated in the following discourses:

"We feel good about how we were brought up. Our parents said that the Catholic religion is living with God, and I want to live with Him” (Daisy).

"I'm not going to renounce the baptism that my parents gave me. It's everything” (Hydrangea.

Spirituality/religiosity and their importance in encouraging life emerged in the statements of participants in sentences such as "gives us strength to cope with difficulties" and "gives courage by prayer" (Lily).

"Religion gives you an inner strength" (Amaryllis).

"There is prayer in everything [...] it gives us courage" (Rose).

The answers were varied, however, in relation to the experience of religiosity and prayer, as the elderly did not always find solace in spirituality/religion when faced with the obstacles and difficulties of life. Narcissus reported that he was a "consecrated pastor" and that he "worked as an evangelizer with his church" before coming to the LTCF. He said that his religion is like a "mission, because he prays for the many who need it and this is the work he is doing now".

Bromeliad says that religiosity has helped her through the most difficult times, such as when her husband had a stroke. In the case of Azalea and Hortensia, however, the confrontation of affective losses and the loss of autonomy proved difficult, resulting in reflection and questioning about the spiritual dimension, as expressed in the following discourse:

"Religion isn't very important. I miss my family. I've been a widow for six years. It changed my life and not for the better" (Azalea).

"Is it worth it? I've lived here for three years, against my wishes" (Hydrangea).

Hydrangea also said: "I pray that I will die, I'm tired". The expression suggests that she believes in the comfort of faith in a higher being. 
Old age, considered the last stage of life, refers to finitude. When a person becomes aware of existential finitude, the dimension of spirituality emerges and becomes a recurring issue. The death of parents, family and friends causes feelings suppressed during most of our lives but which now become significant. The importance of spirituality or religion is also exalted as capable of diminishing the despair that individuals feel with the approach of the end of their biological life $\mathrm{f}^{6,14,20}$.

When exploring the relationship between the different facets of spirituality and positive mental well-being in old age it was observed that well-being was positively predicted both by the transcendental dimension and by the dimension of others. This reveals that when faced with stressful situations the elderly can find comfort in a sense of connection with something that goes beyond the self, in the same way that they find solace in a sense of connection with others, if this is their main way of experiencing spirituality ${ }^{11}$.

When questioned about the frequency with which they participate in religious ceremonies or attend religious service, seven of the elderly persons responded that they do so monthly or weekly, depending on the provision of these ceremonies by the institution; only one reported never participating in such ceremonies, expressing, however, the will to do so. This result collaborates the findings of a study that sought to analyze whether religiosity exerts a mediating effect on the relationship between socio-demographic factors, multimorbidity and health-related quality of life in the elderly living in the community, in which religious practice was weekly and performed mainly by elderly women. The practice of religiosity in this study suggests an association with quality of life as it provides adherence to a religious community and can thus generate social support ${ }^{21}$.

In a study that investigated the relationship between spiritual/religious coping strategies and quality of life in institutionalized elderly people, religiosity/spirituality was shown to play a significant role in preventing problems, helping with coping, recovering or adapting to health situations, and also played a comforting role, being applied in cases of stress, such as the institutionalization of the elderly ${ }^{15}$.

Illness and healing are often attributed to a superior being, specific to each religion, which leads to cognitive strategies in which the individual appeals to God in search of improvement in their health ${ }^{14}$. This search for meaning encourages people to overcome and understand the difficulties that arise during life. However, it is observed that not all people who declare that they belong to a religion have such an experience, which is demonstrated in the statements of Hydrangea and Azalea, who claim not to see religion as a source of overcoming their difficulties.

However, other elderly persons expressed the view that the experience of spirituality/religiosity "helps a lot", as it places more importance on the spiritual plane, such as Narcissus, who says: "After I discovered the gospel I learned a lot", and "I accept the changes", and when Hydrangea says bluntly: "If I am here it is because of my faith, otherwise I would have killed myself".

Spirituality/religiosity as a meaning for life and a source of renewal, fulfillment and happiness

Regarding degrees of spirituality/religiosity, seven participants classified themselves as "very religious and/or spiritual", highlighting the important role of prayers to serve others and to feel happy.

\footnotetext{
"Spirituality gives meaning to my life" (Narcissus).

"Prayer is important for helping others" (Bromeliad).

"Doing good gives me peace of mind [...] it gives me an inner strength to help people" (Amaryllis).

“It does me good when I do good" (Jasmin).

"If I wasn't happy in my religion, I was sad. So I'm happy with it, with my religion" (Daisy).
}

In a study about happy aging and its association with positive psychological sources carried out with 279 elderly people in Belgium, the results indicated that well-being was positively predicted by the 
spirituality experienced through the connection with the transcendent and with others ${ }^{11}$.

Spirituality supports finding meaning in existence, capable of generating psychic forces to face the anguish, disease and dilemmas that occur on a daily basis and especially in situations of suffering and death ${ }^{22}$. It is possible to establish connections between spirituality, religion, fulfillment and happiness as promoters of meaning in life and "share our values with those who believe in the realization of the vocation of man as a happy being [...] [and] in the construction of a decent and better future for all”'14.

Old age is a privileged period for valuing and enjoying these motivating qualities of subjective well-being. However, the pursuit and achievement of these subjective values of well-being stem from an educational process. "Education about longevity is an obligation that brings the challenge of greater understanding about the existential and finite human condition of us all’"12.

In terms of the religious and/or spiritual practices of the elderly in this study, the majority of prayer was performed in the LTCF itself. There were also practices of reading the sacred text of a religion and retreating to an isolated place for prayer. But Azalea describes a lack of religious ceremonies when she says "I think it is important to participate in church activities".

The understanding of spirituality/religiosity as renewal and fulfillment emerges in the discourse of Narcissus and Daisy:

"Because it fills all the gaps I had before. Now I have Jesus in my heart [...]. I hope that the day I leave here I'll be with Jesus" (Narcissus).

"It makes sense of things. Not a lot, but enough. We sit in silence and speak to God and renew our lives" (Daisy).

For Kuznier ${ }^{23}$, the elderly understand that life only makes sense when there is harmony in coexistence with others and spirituality is a key point in achieving this goal, enabling the fullest possible experience. This understanding is in line with the results of a comparative study conducted with 196 subjects, which aimed to evaluate whether the perception of quality of life is associated with strategies of religiousspiritual coping of patients in palliative care. The present study revealed that healthy participants with better quality of life scores had greater religiousspiritual coping ${ }^{24}$. Another study, which evaluated the quality of life of chronic kidney patients on hemodialysis, through the WHOQOL-bref and WHOQOL-Spirituality, Religion and Personal Beliefs, found that the participants presented high quality of life scores, specifically in the dimensions related to the aforementioned spirituality, religion and personal beliefs ${ }^{25}$.

In the process of aging, joy, happiness, hope, motivation and life goals or projects, as well as feelings of sadness, insecurity and abandonment are "closely related to the psychic dimension, to personality, optimism, resilience, gratitude and the presence of high scores for positive emotions" ${ }^{26}$.

In summary, spirituality as a promoter of renewal, fulfilment and happiness is structured around subjective well-being, autonomy, independence, creativity; being able to set goals and having the means to execute them; in coping with the challenges of life; acting in accordance with the inner values of consciousness; having individual or motivational expectations, being cheerful, content and trying to overcome anxiety and anguish; enjoying one's home environment and cultivating friendship; dealing with losses and exercising resilience; having personal beliefs and being able to exercise self-care until death.

The limitations of the present study are related to its transversal design and the impossibility of generalizing the results for the wider elderly population residing in LTCF. We therefore suggest the carrying out of further studies, as the experience of spirituality in institutionalized elderly people and its meaning in the context of situations of life needs to be broadened by scientific evidence. The present study could also be complemented by extending the sample to include elderly people from different institutions and cities, and even expanding the instrument used to investigate other aspects of the life of the elderly in LTCF and their relationships with spirituality. 


\section{CONCLUSION}

All the elderly people who composed the sample were religious and considered it to be important in their lives, suggesting, on several occasions, the presence of a cultural and traditional tradition, transmitted from parents to children, that makes religion so present in their lives.

The reasons given by the interviewees for dedicating themselves to their spirituality/religiosity were diverse, predominating the view that spiritual practice is related to positive events and in the perseverance to face difficult moments. However, since most believe that religion helps them face difficulties, it was found that when affective losses are involved, the importance attributed to religion is questioned, a reflection of the limited religious activities offered to the elderly residents in the longterm care facility compared to what they were used to before institutionalization.

\section{REFERENCES}

1. Instituto Brasileiro de Geografia e Estatística. Síntese de indicadores sociais: uma análise das condições de vida da população brasileira [Internet]. Rio de Janeiro: IBGE; 2016 [acesso em 8 out. 2017]. Disponível em: http://biblioteca.ibge.gov.br/ visualizacao/livros/liv98965.pdf

2. Instituto de Pesquisa Econômica Aplicada. Infraestrutura social e urbana no Brasil: Subsídios para uma agenda de pesquisa e formulação de políticas públicas. Condições de funcionamento e infraestrutura das instituições de longa permanência para idosos no Brasil [Internet]. [Sem Local]: IPEA; 2011[acesso em 22 out. 2017]. Disponível em: http:// www.ipea.gov.br/portal/images/stories/PDFs/ comunicado/110524_comunicadoipea93.pdf

3. Freitas EV, Py L, editores. Tratado de geriatria e gerontologia. 4. ed. Rio de Janeiro: Guanabara Koogan; 2017.

4. Oliveira JM, Rozendo CA. Instituição de longa permanência para idosos: um lugar de cuidado para quem não tem opção? Rev Bras Enferm. 2014;67(5):773-9.

5. Fagundes KDL, Esteves MR, Ribeiro JHM, Siepierski CT, Silva JV, Mendes M. Instituições de longa permanência como alternativa no acolhimento das pessoas idosas. Rev Salud Pública. 2017;19(2):210-4.
All participants reported that spirituality/religiosity provides meaning in their lives. The practices used to worship the religion/spirituality of each subject in the study can be diverse: individual prayers or experience and reflection on their own existence.

The elderly in this study emphasized the practice of spirituality in its different forms of manifestation as a way of coping with difficulties, morbid conditions and the finitude of life, which were subtly present in this segment of the institutionalized elderly population.

The experience of spirituality/religiosity proved to be an important strategy for achieving well-being when faced with life situations. For its effective application as a way of caring for institutionalized elderly people, however, it is important to identify and understand their preferences and spiritual practices more accurately, as well as the relationship between such aspects and well-being, considering the subjectivities and context of how they are expressed.

6. Lucchetti G. Medical students, spirituality and religiosity: results from the multicenter study. BMC Med Educ. 2013;13:162-75.

7. Weber SR, Pargament KI. The role of religion and spirituality in mental health. Curr Opin Psychiatr. 2014;27(5):358-63.

8. Ivtzan I. Linking religion and spirituality with psychological well-being: examining self-actualisation, meaning in life, and personal growth initiative. J Relig Health. 2013;52(4):915-29.

9. Braghetta CC. Desenvolvimento e validação de um instrumento para avaliar a espiritualidade: Escala de Atitudes Relacionadas a Espiritualidade (ARES) [Dissertação]. São Paulo: Faculdade de Medicina da Universidade de São Paulo, Programa de Psiquiatria; 2017.

10. Panzini RG. Validação brasileira do Instrumento de Qualidade de Vida/espiritualidade, religião e crenças pessoais. Rev Saúde Pública. 2011;45(1):153-65.

11. Thauvoye E. Spirituality and well-being in old age: exploring the dimensions of spirituality in relation to late-life functioning. J Relig Health. 2017;56(5):333-342.

12. Siviero I, Rosin N, organizadores. Envelhecimento humano, espiritualidade e cuidado. Vol. 2, Espiritualidade e missão. Passo Fundo: IFIBE; 2014. Introdução. 
13. Gutz L, Camargo BV. Espiritualidade entre idosos mais velhos: um estudo de representações sociais. Rev Bras Geriatr Gerontol. 2013;16(4):793-804.

14. Pessini L. Bioética, espiritualidade e a arte de cuidar em saúde. In: Siviero I, Rosin N, organizadores. Envelhecimento humano, espiritualidade e cuidado: Vol. 2, Espiritualidade e Missão. Passo Fundo: IFIBE; 2014. p. 31-83.

15. Vitorino LM, Vianna LAC. Coping religioso/ espiritual de idosos institucionalizados. Act Paul Enferm [Internet]. 2012 [acesso em 20 out. 2017];25(n. spec 1):136-42. Disponível em: http://www.scielo. $\mathrm{br} /$ scielo.php?script=sci_arttext\&pid=S010321002012000800021\&lng=en\&nrm=iso

16. Born T, organizadora. Cuidar melhor e evitar a violência: manual do cuidador da pessoa idosa. Brasília,DF: Secretaria Especial dos Direitos Humanos, Subsecretaria de Promoção e Defesa dos Direitos Humano; 2008. O cuidador familiar da pessoa idosa. p. 59-63.

17. Brasil. Resolução de Diretoria Colegiada. RDC $\mathrm{n}^{\circ} 283$, de 26 de setembro de 2005. Aprova o Regulamento Técnico que define normas de funcionamento para as Instituições de Longa Permanência para Idosos, de caráter residencial. Diário Oficial da União. 27 set. 2005.

18. Bardin L. Análise de Conteúdo. 4a . ed. São Paulo: Edições 70; 2016.

19. Chaves LJ, Gil CA. Concepções de idosos sobre espiritualidade relacionada ao envelhecimento e qualidade de vida. Ciênc Saúde Coletiva. 2015;20(12):3641-52.
20. Best M, Butow P, Olver I. Do patients want doctors to talk about spirituality?: a systematic literature review. Patient Educ Couns. 2015;98(15):1320-8.

21. Abdala GA, Kimura M, Duarte YAO, Lebrão ML, Santos B. Religiosidade e qualidade de vida relacionada à saúde do idoso. Rev Saúde Pública. 2015;49(55):1-9.

22. Reginato V, Benedetto MAC, Gallian DMC. Espiritualidade e saúde: uma experiência na graduação em medicina e enfermagem. Trab Educ Saúde. 2016;14(1):237-55.

23. Kuznier TP. O significado do envelhecimento e do cuidado para o idoso hospitalizado e as possibilidades do cuidado de si [Dissertação]. Curitiba: Universidade Federal do Paraná, Programa de Pósgraduação em Enfermagem; 2007.

24. Matos TDS, Meneguin S, Ferreira MLS. Qualidade de vida e coping religioso-espiritual em pacientes sob cuidados paliativos oncológicos. Rev Latinoam Enferm. 2017;25:910-21.

25. Rusa SG. Qualidade de vida/espiritualidade, religião e crenças pessoais de adultos e idosos renais crônicos em hemodiálise. Rev.Latinoam Enferm. 2014;22(5):911-7.

26. Zenevicz T, Moriguchi Y, Madureira VF. O vivenciar da espiritualidade nas alegrias e tristezas experienciadas no processo de envelhecimento e atitudes tomadas frente a elas. Rev Bras Ciênc Envelhec Hum. 2012;9(1):98-108. 